ПАНЧЕНКО С. В., д-р техн. наук, професор (Український державний університет залізничного транспорту),

ГРИЦУК Ю. В., канд. техн. наук, доцент (Донбаська національна академія будівництва і архітектури),

ВОЛКОВ Ю. В., аспірант (Харківський національний автомобільно-дорожній університет)

\title{
Особливості моделювання процесів оцінювання поточного і прогнозованого технічного стану автомобіля під час експлуатації в умовах ITS
}

Стаття містить результати обтрунтування особливостей моделювання процесів оцінювання поточного $i$ прогнозованого технічного стану автомобіля і транспортних засобів у цілому під час їх експлуатації. Показані особливості проведення дистаниійного моніторингу параметрів стану транспортного засобу в системі інформаційного забезпечення в умовах ITS. Подано формальне відображення процесу моніторингу технічного стану транспортного засобу в реальних умовах експлуатації.

Ключові слова: транспортний засіб, дистанційний моніторинг, умови експлуатації, технічний стан, параметр.

\begin{abstract}
Вступ
Дистанційний моніторинг i прогнозування параметрів технічного стану автомобіля в процесі експлуатації в умовах інтелектуальних транспортних систем (ITS) $є$ важливим науково-практичним завданням. Отримані параметри технічного стану використовуються в бортових системах автомобіля, які надають водієві допомогу в управлінні, а також і в роботі технічних служб експлуатації автомобільного транспорту (АТ) при визначенні та прогнозуванні параметрів їх технічного стану [1].
\end{abstract}

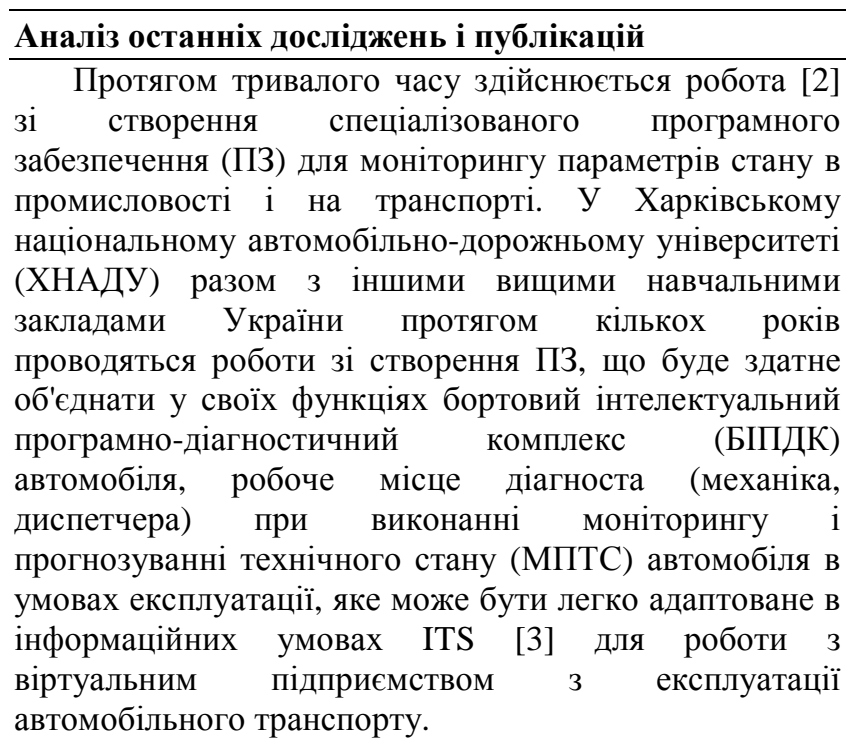

() С. В. Панченко, Ю. В. Грицук, Ю. В. Волков, 2017
Існуючі інтелектуальні комплекси оснащені відповідним ПЗ, адаптованим для виконання своїх спеціалізованих завдань [3]. Однак, 3 урахуванням удосконалення математичного апарату, існує актуальна необхідність вирішення питання оснащення комплексним ПЗ усієї системи, яка застосовується для МПТС автомобіля в умовах експлуатації.

\section{Визначення мети та задачі дослідження}

Задача визначення особливостей моделювання процесів оцінювання поточного i прогнозованого технічного стану автомобіля під час експлуатації в умовах ITS може бути вирішена використанням програмно-діагностичного комплексу, для чого необхідно обгрунтувати особливості, функції і зв’язки основних його елементів і особливостей отримання інформації про умови експлуатації та взаємодії для здійснення інформаційного обміну при виконанні моніторингу в умовах ITS.

\section{Основна частина дослідження}

Для ефективної роботи автомобілів необхідно постійно здійснювати їх конструктивну модернізацію i використовувати нові технологічні та інформаційні методи і підходи до вибору стратегії їх технічного обслуговування та ремонту (ТО і Р). Конструктивна модернізація автомобілів полягає у широкомасштабному використанні електронних (комп'ютерних, інформаційних) систем, які контролюють різноманітні процеси, що відбуваються під час виконання поставлених перед ними завдань, забезпечують інформатизацію означених процесів, оптимізують та планують їх роботу, а також 
І Н Ф О Р М А Ц Й Н О - КЕ Р У Ю Ч І С И С ТЕ МИ Н А З А Л І З Н ИЧ Н О М У Т Р А Н С П О Р Т І

створюють умови для проведення моніторингу параметрів їх технічного стану. При цьому важливим завданням є оптимізація та обгрунтування комплексу технічних дій для покращення ТО або Р й забезпечення високого коефіцієнта технічної готовності автомобілів в умовах експлуатації, що постійно змінюються у часі [4].

Використання автомобіля в нестаціонарних умовах експлуатації вимагає постійного контролю технічних параметрів його фактичного стану, проведення необхідних технічних дій 3 обслуговування для забезпечення належного працездатного стану. Подібна інтерпретація умов використання автомобілів можлива лише за рахунок моніторингу технічного стану, який грунтується на обробці апріорної інформації, безперервній діагностиці та прогнозуванні параметрів ïх технічного стану. У зв'язку з цим перед науковцями, що займаються питаннями експлуатації автомобілів і взагалі транспортних засобів (Т3), стоїть проблема забезпечення повноцінного зв'язку між процесами їх експлуатації і параметрами умов експлуатації $[5,6]$ й узагальнення та удосконалення методів прогнозування параметрів технічного стану Т3 [4]. Урахуванню та контролю параметрів технічного стану ТЗ в умовах експлуатації приділяється багато уваги, тому питання побудови систем моніторингу в різних сферах діяльності ТЗ не втрачають своєї актуальності [7].

Моніторинг трактують як систему заходів спостереження та контролю, що проводяться для оцінювання стану об'єкта дослідження, аналізу процесів, що відбуваються, та своєчасного виявлення тенденцій його зміни [7]. Основним принципом організації системи моніторингу ТЗ $є$ безперервність пооб'єктного контролю та урахування інформації для його ефективного забезпечення, а також прийняття рішень щодо першочерговості впровадження заходів реагування, вирішення завдань керування ТЗ. Моніторинг $\epsilon$ одним із складових елементів системи управління Т3 в умовах експлуатації, особливості якої (цілі, завдання, об'єкти) зумовлюють додаткові вимоги до способу виконання моніторингу та системи оцінювальних показників. Створення інформаційного простору моніторингу ефективності експлуатації Т3 в основних процесах 3 урахуванням ієрархічності та багатооб'єктності умов експлуатації $\epsilon$ важливим завданням [7 - 10].

Моніторинг Т3 - одна 3 функцій менеджменту параметрів стану і умов експлуатації Т3, побудована на збиранні інформації про об'єкт дослідження і спрямована на дотримання режимів функціонування, встановлених значень показників використання та виконання запланованих заходів. Це комплекс заходів для реалізації основних функцій: ідентифікації ТЗ, спостереження та оцінювання параметрів технічного стану ТЗ, прогнозування та контролю параметрів, що конкретизовані специфікою призначення Т3, в процесах дослідження та поставленими задачами. Це певним чином організований інструмент інформаційного забезпечення управління експлуатацією Т3 для контролювання, оцінювання, аналізування і прогнозування технічного стану об'єкта управління на основі безперервного процесу збору, обробки, відображення інформації про параметри технічного стану об'єкта дослідження та його показники використання [7].

Процеси технічної експлуатації сучасних Т3 доцільно розглядати як складну динамічну i інформаційну систему, функціонування якої відбувається в результаті взаємодії різних випадкових факторів як з боку внутрішніх процесів в їх агрегатах та системах, так і при дії (під впливом дій) процесів (умов) зовнішнього (навколишнього) середовища $[4,6]$.

Ефективність функціонування Т3 як складної технічної системи залежить від параметрів його технічного стану [4]. У зв'язку з цим випливає проблема керування параметрами технічного стану ТЗ в умовах експлуатації на основі даних, отриманих у процесі моніторингу основних параметрів технічного стану та при їх прогнозуванні. Розв'язанню цієї проблеми присвячені численні роботи Барзиловича Є. Ю. [11], Міхліна В. М. [12], Полянського А. С [13], Бажинова А. В. [14], Волкова В. П. [15], Кравченка О. П. [16], Сухарева Є. А. [17], Ауліна В. В. [18, 19], Грицука І. В. [21-23] Матейчика В. П. [23], Гутаревича Ю. Ф. [24] тощо.

Дослідниками виявлено [5, 20], що зовнішнє (навколишнє) середовище може вносити невизначеність та випадковість вихідних даних i ситуацій умовами експлуатації Т3 та випадковим чином змінювати характер взаємодії між складовими частинами агрегатів та систем самого ТЗ. У таких динамічних i інформаційних системах можуть виникнути випадкові збурення, що являють собою помилки вимірювання діагностичних параметрів та похибки при перетворенні інформації, дії різного роду перешкод, внаслідок появи неврахованих, але об' єктивно діючих причин $[4,7]$.

Суттєва просторова протяжність, складність і розподіленість реальних умов експлуатації Т3 і транспортної інфраструктури зі своїми особливостями i різноманіттям можуть вважатися об'єктом автоматизації сучасних ТЗ як складних систем в інформаційних умовах ITS.

Знання основ теорії експлуатації ТЗ $є$ фундаментом при розробленні прогресивних систем нормування i планування на транспорті за допомогою сучасних інформаційних систем [24]. Більшість практичних завдань у процесі удосконалення методів оперативного управління працездатності автомобіля, які вирішують технічні служби експлуатації Т3, мають інформаційну складову оцінювання: дорожніх умов експлуатації ТЗ у 
частині висоти дороги над рівнем моря, повздовжнього профілю (рельєфу місцевості), типу і стану дорожнього покриття; ремонту, будівництва i обслуговування об'єктів дорожньої інфраструктури; їх моніторинг; прогнозування можливих аварійних ситуацій, транспортних умов у частині насиченості i інтенсивності руху Т3, особливостей вантажу, режиму i швидкості руху; атмосферно-кліматичних умов, культури експлуатації Т3 тощо [26, 27, 5]. Перелічені та подібні до них завдання поки в основному вирішуються застарілими методами, які вже не забезпечують необхідної якості і ефективності [26]. Оцінка умов експлуатації, аналіз планів і профілів автомобільних шляхів, як правило, складаються при визначенні лінійних норм витрати палива вручну або за допомогою обчислювальної техніки в паперовому вигляді, оновлення карт і схем здійснюється вкрай рідко, дані про стан більшості об'єктів не систематизовані i, відповідно, важкодоступні. Така ситуація ускладнює завдання керування класифікацією умов експлуатації Т3 в інформаційних умовах ITS.

На основі виконаних у ХНАДУ $[25,5]$ досліджень розроблена єдина експлуатаційна класифікація умов роботи ТЗ, що базується на офіційних документах. Класифікація успішно використовується для будь-яких експлуатаційних розрахунків і має пряме відношення до технічної експлуатації автомобілів і Т3 у цілому, тому що визначає навантажувальні, швидкісні і температурні режими роботи агрегатів Т3 [25, 5]. Тому висвітлення i розвиток цього питання при дистанційному визначенні умов експлуатації Т3 у реальному часі в умовах ITS при здійсненні дистанційного моніторингу параметрів технічного стану Т3 можна вважати доцільним.

Система моніторингу технічного стану автомобілів i Т3 у цілому в реальних умовах експлуатації складається 3 великої кількості елементів, які характеризуються відповідними вихідними умовами, знаходяться на різних ієрархічних рівнях і мають свої особливості функціонування. Це $є$ складна динамічна i інформаційна система із чітко впорядкованою ієрархічною структурою, розгалуженою мережею взаємозв'язків між ії елементами, що розвивається в просторі i часі. Діяльність складної виробничої системи визначається технологічними процесами, які реалізують іiі суб'єкти відповідно до цільової спрямованості в рамках предметної області [4, 7]. Кожен суб'єкт моніторингу має властиві процедури алгоритми функціонування, розрахунку, результати яких використовуються в алгоритмах суб'єктів процесу моніторингу різних ієрархічних рівнів. Після завершення процедур управління та удосконалення відповідних технологічних процесів відбувається зміна стану предметної області, тобто зміна (підвищення) рівня оцінки працездатності об'єкта дослідження. У цілому модель функціонування суб'єктів моніторингу ефективності функціонування може бути подана як сукупність таких компонентів: моделі об'єктів, що беруть участь у структурних зв'язках; моделі параметрів, що визначають результати функціонування суб'єктів; моделюючих алгоритмів, що встановлюють правила функціонування об'єктів і зміни значень їх параметрів тощо [4, 7]. Така модель є динамічною та інформаційною і відображає не лише поточний стан ТЗ і умов експлуатації, але й зміну їх стану в часі.

Таким чином, у загальному розумінні процес моніторингу технічного стану Т3 у реальних умовах експлуатації $\epsilon$ процесом трансформації інформації параметрів технічного стану i процесів функціонування автомобіля і Т3 у цілому та умов їх експлуатації. Формально [8, 27 - 29] це відображення має вигляд:

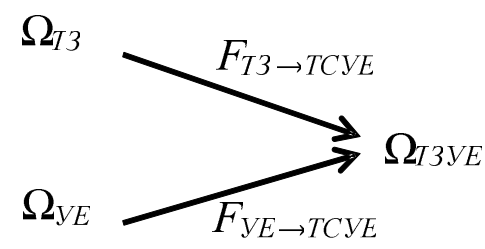

де $\Omega_{T 3}$ - множина моделей параметрів технічного стану і процесів функціонування Т3; $\Omega_{\text {УE }}$ - множина моделей параметрів умов експлуатації Т3; $\Omega_{T 3}$ уE множина моделей параметрів технічного стану Т3 у

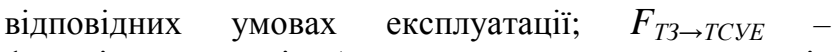
функціональне відображення моделей параметрів технічного стану і процесів функціонування Т3; $F_{\text {УЕ } \rightarrow \text { TСУЕ }}$ - функціональне відображення моделей параметрів умов експлуатації Т3.

\section{Висновок}

У статті обгрунтувано особливості моделювання процесів оцінювання поточного i прогнозованого технічного стану автомобіля і транспортних засобів у цілому під час їх експлуатації в умовах ITS.

\section{Список використаних джерел}

1. Sivasubrahmaniyan, A., Jaishwal, A., Warrier, G., Tharaneetharan, S. et al., [Электронный pecypc] "A Systematic Approach of Improving Reliability Process through Development and Application of OnBoard Diagnostics System, for Commercial Vehicle," SAE Technical Paper 2015-26-0101, 2015, Published 01/14/2015, doi:10.4271/2015-26-0101. - Режим доступа к ресурсу: http://papers.sae.org/2015-26$\underline{0101-10.12 .2015}$.

2. Павлов, К. С. Модели выбора и замены оборудования в производственных системах машиностроительных предприятий [Электронный 
pecypc] / К. С. Павлов, Е. Н. Хоботов // Автоматика и телемеханика. - 2015. - № 2. C. 125-140. - ISSN 0005-1179. «Models for equipment selection and upgrade in manufacturing systems of machine building enterprises». - Режим доступа: http://mi.mathnet.ru/rus/at/y2015/i2/p125 12.03.2013.

3. Мониторинг, диагностирование и прогнозирование параметров технического состояния транспортных средств в условиях ITS [Текст] / А. В. Предко, Ю. В. Грицук, И. В. Грицук и др. // Альтернативные источники энергии в транспортно-технологическом комплексе: проблемы и перспективы рационального использования: сб. науч. тр. по материалам ежегодных конференций (Воронеж, 27 - 28 апреля 2015 г.). - Воронеж, 2015. - Вып. 2. - С. 126-131.

4. Гриньків, А. В. Використання методів прогнозування в керуванні технічним станом агрегатів та систем транспортних засобів [Текст] / А. В. Гриньків // Техніка в сільськогосподарському виробництві, галузеве машинобудування, автоматизація. - 2016. - Вип. 29. - С. 25-32.

5. Говорущенко, Н. Я. Системотехника автомобильного транспорта (расчетные методы исследований) [Текст]: монографія / Н. Я. Говорущенко. - Харьков: ХНАДУ, 2011. 292 c.

6. Говорущенко, Н. Я. Техническая эксплуатация автомобилей [Текст] / Н. Я. Говорущенко. Харьков: Вища школа. Изд-во при Харьк. ун-те, 1984. - 312 c.

7. Давиденко, Л. В. Побудова інформаційного простору моніторингу ефективності енергоспоживання в системах комунального водопостачання [Текст] / Л. В. Давиденко, В. А. Давиденко // Техніка в сільськогосподарському виробництві, галузеве машинобудування, автоматизація. - 2016. Вип. 29. - С. 178-184.

8. Троицкий-Марков, Т. Е. Принципы построения системы мониторинга энергоэффективности [Текст] / Т. Е. Троицкий-Марков, Д. В. Сенновский // Мониторинг. Наука и безопасность. - 2011. № 4. - С. 34-39.

9. Функції енергетичного моніторингу складних виробничих систем та їх завдання для підвищення рівня енергоефективності [Текст] / Л. В. Давиденко, В. А. Давиденко, Н. В. Коменда та ін. // Проблеми енергозабезпечення та енергозбереження в АПК України: Вісник ХНТУСЕ. Технічні науки. - Харків: ХНТУСЕ, 2014. - Вип. 153. - С.125-127.

10. Розен, В. П. Формування інформаційного поля для оцінювання рівня енергоефективності систем комунального водопостачання [Текст] /
В. П. Розен, Л. В. Давиденко, В.А. Давиденко // Вісник КДПУ ім. М. Остроградського. Кременчук: КДПУ, 2010. - Вип. 4 (63). - С. 50-53.

11. Барзилович, Е. Ю. Эксплуатация авиационных систем по состоянию [Текст]: монография / Е. Ю. Барзилович, В. Ф. Воскобоев. - М.: Транспорт, 1981. - 197 с.

12. Михлин, В. М. Управление надежностью сельскохозяйственной техники [Текст] / В.М. Михлин. - М.: Колос, 1984. - 335 с.

13. Полянський, А. С. Підвищення точності прогнозування надійності агрегатів і систем техніки на стадії проектування [Текст] / А.С. Полянський // Вісник ХТУ (ХПІ): сб науч. тр. - Харків: ХПІ, 2002. - №10, Т.1. - С. 130-134.

14. Бажинов, А.В. Прогнозирование остаточного peсурса автомотора [Текст]: монография / А.В. Бажинов. - Харьков: ХГАДГУ, 2001. - 96 с.

15. Волков, В. П. Интеграция технической эксплуатации автомобилей в структуре и прогрессы интеллектуальной транспортной системы [Текст]: монография / В. П. Волков, В. П. Матейчик, П. Б. Никонов [и д.р.]; под. ред. В. П. Волкова. - Донецк: Изд-во "Ноудмедж" (Донецкое отделение), 2013. - 398 с.

16. Кравченко, О. П. Прогнозування фактичного терміну експлуатації та призначення нормального ресурсу шин вантажних автомобілів [Текст] / О. П. Кравченко, О. П. Сакно, О.В.Лучіков // Вісник ДААТ. - 2011. - №4. - С. 89-95.

17. Сухарев, Э. А. Теория эксплуатационной надежности машин [Текст]: монография / Э. А. Сухарев. - Ровно: Изд-во УГАВХ, 1997. $162 \mathrm{c}$.

18. Аулін, В. В. Забезпечення та підвищення експлуатаційної надійності транспортних засобів на основі використання методів теорії чутливості [Текст] / В. В. Аулін, А.В. Ериньків, Т.М. Замота // Вісник Інженерної академії України. - 2015. - №.3. - С. 66-73.

19. Аулін, В. В. Проблеми підвищення експлуатаційної надійності та можливості удосконалення стратегії технічного обслуговування мобільної сільськогосподарської техніки [Текст] / В.В.Аулін, А. В. Ериньків // 3б. наук. праць Кіровоградського національного технічного університету: Техніка в сільськогосподарському виробництві, галузеве машинобудування. - Кіровоград: Кіровоградський нац. техн. ун-т, 2015. - № 28. - С. 126-132.

20. Грицук, И. В. Особенности мониторинга, диагностирования и прогнозирования параметров технического состояния транспортных средств в процессе эксплуатации в условиях ITS [Текст] / И. В. Грицук // Сучасні енергетичні установки на транспорті i технології та обладнання для їх 
обслуговування: міжнар. наук.-техн. конф., 24-25 вересня 2015 р.: зб. матеріалів. - Херсон: Херсонська державна морська академія, 2015. C. 54-55.

21. Грицук, I. B. Особливості структури інформаційного програмного комплексу моніторингу, діагностування i прогнозування технічного стану транспортного засобу в умовах ITS [Текст] / I. В. Грицук // Новітні технології в автомобілебудівництві та транспорті: міжнар. наук.-техн. конф., 15-16 жовтня 2015 р.: зб. матеріалів. - Харків: ХНАДУ, 2015. C. 123-125.

22. Особливості інформаційного обміну в процесі дистанційного моніторингу технічного стану i управління працездатністю енергоустановок залізничного транспорту 3 двигунами внутрішнього згорання [Текст] / I. В. Грицук, С. В. Панченко, А. О. Каграманян [та ін.] // Залізничний транспорт України. - 2015. - №5. C. 41-45.

23. Контроль роботи транспортного двигуна 3 використанням інформаційних технологій [Текст] / В. П. Матейчик, В. П. Волков, П. Б. Комов [та ін.] // Двигатели внутреннего сгорания: науч.-техн. журнал. - Харьков: НТУ “ХПИ», 2013. - №2. C. 27-31.

24. Обгрунтування структури вимірювального комплексу для дослідження роботи двигуна внутрішнього згорання транспортного засобу 3 системою прогріву й тепловим акумулятором в процесі пуску i прогріву [Текст] / Ю. Ф. Гутаревич, І. В. Грицук, Д. С. Адров [та ін.] // Вісник Національного технічного університету «ХПІ»: зб. наук. праць. Сер. Автомобіле- та тракторобудування. - Харків: НТУ «ХПІ», 2014. № 10 (1053). - С. 55-62.

25. Говорущенко, Н. Я. Системотехника транспорта (на примере автомобильного транспорта) [Текст] / Н. Я. Говорущенко, А. Н. Туренко. - Харьков: РИО ХГАДТУ, 1999. - 468 с.

26. ГИС мониторинга транспортных сетей [Электронный ресурс] / В. В. Алексеев, Н. И. Куракина, Н. В. Орлова [и др.] // Data+. Геоинформационные системы для бизнеса и общества. - 2014. - №2 (69). - Режим доступу: https://www.dataplus.ru/news/arcreview/detail.php?ID $=17802 \&$ SECTION_ID $=1058$.

27. Анпілогов, П. I. Принципи створення автоматизованої системи експертної оцінки тарифів на послуги водопостачання та водовідведення [Текст] / П. І. Анпілогов, В. М. Михайленко // Системні дослідження та інформаційні технології. - 2008. - №3. - С. 44-51.

28. Анфилатов, В. С. Системный анализ в управлении [Текст] / В. С. Анфилатов, А. А. Емельянов,
А. А. Кукушкин; под ред. А. А. Емельянова. - М.: Финансы и статистика, 2002. - 268 с.

29. Борукаев, 3. Х. Компьютерная модель мониторинга энергоэффективности: аспекты информационного моделирования [Текст] / 3. Х. Борукаев, К. Б. Остапченко, Л. И. Ерицюк // Енергетика та електрифікація. - 2007. - №1. C. 3-7.

С. В. Панченко, Ю. В. Грицук, Ю. В. Волков. Особенности моделирования процессов оценки текущего и прогнозируемого технического состояния автомобиля при эксплуатации в условиях ITS. В статье представлены результаты обоснования особенностей моделирования процессов оценивания текущего и прогнозируемого технического состояния автомобиля и транспортных средств в целом при их эксплуатации. Показаны особенности проведения дистанционного мониторинга параметров состояния транспортного средства в системе информационного обеспечения в условиях ITS. Представлено формальное отображение процесса мониторинга технического состояния транспортного средства в реальных условиях эксплуатации.

Ключевые слова: транспортное средство, дистанционный мониторинг, условия эксплуатации, техническое состояние, параметр.

S.V. Panchenko, Yu.V. Gritsuk, Yu.V. Volkov. The peculiaritiies of assessing process design of current and projected technical condition of a vehicle during operation under ITS. The article presents the results of study assessment process modeling features current and projected technical condition of the car and vehicles in general during their operation. The following features of remote monitoring parameters of the vehicle information system in terms of ITS. It is confirmed that the monitoring of the vehicle is one of the management functions and parameters of the conditions of its operation, based on gathering information and research facility focused on adherence operation set values of use and implementation of the planned measures. It is shown that significant spatial extent, complexity and distribution real operating conditions of vehicles and transport infrastructure with its variety of features and can be considered an object of automation of modern vehicles as complex systems for information under ITS. The formal display of monitoring technical condition of the vehicle under real operating conditions.

Keywords: vehicle, remote monitoring, operating conditions, technical condition, setting.

Надійшла 15.03.2017p. 
Панченко Сергій Володимирович, доктор технічних наук, професор, ректор, Український державний університет залізничного транспорту, Харків, Україна. E-mail: tz@kart.edu.ua.

Грицук Юрій Валерійович, кандидат технічних наук, доцент кафедри загальної інженерної підготовки, Донбаська національна академія будівництва i архітектури, м. Краматорськ; Україна. E-mail: yuri.gritsuk@gmail.com.

Волков Юрій Володимирович, аспірант кафедри технічної експлуатації і сервісу автомобілів, Харківський національний автомобільно-дорожній університет, м. Харків; Україна. E-mail: yura_volkov_88@mail.ua.

Panchenko S.V., Doctor of Techn. Sciences, professor, rector, Ukrainian State University of Railway Transport, Kharkiv, Ukraine. E-mail: tz@kart.edu.ua.

Grytsuk Yurii Valeriyovich, Candidate of Technical Sciences (PhD), Associate Professor at the Department of general engineering training, Donbas National Academy of Civil Engineering and Architecture, Kramators'k, Ukraine. E-mail: yuri.gritsuk@gmail.com.

Volkov Yurii Volodimyrovich, Postgraduate Student at the Department of "Technical operation and service vehicles", Kharkiv National Automobile and Highway University (KhNAHU), Kharkiv, Ukraine. E-mail: yura_volkov_88@mail.ua. 